\title{
Sergey Tolstoguzov*
}

\section{The International Situation in East Asia and the Establishment of a Modern Army and Modern Warfare in Japan: The Memorandum of Takashima Shūhan}

\author{
https://doi.org/10.1515/asia-2017-0078
}

\begin{abstract}
During the Tokugawa bakufu, Japan's foreign policy was under set conditions, generally known as sakoku, meaning 'closed country'. However, the existing regime was not fully closed to the outside world. Contact with foreigners in Nagasaki, Tsushima, and Ryūkyū Islands meant that the country was not completely isolated, but rather experienced a situation in which government policy was aimed at achieving strict control over all contact with the outside world, as part of a larger strategy to monopolize all foreign relations. This paper examines the ideas of Takashima Shirōtayu Shūhan (1798-1866), one of the early Japanese reformers, who argued for the modernization of Japan. Beginning in the 1830s, a Nagasaki bakufu official, Takashima Shūhan, began importing flintlock pistols, known as gewehr rifles, from the Netherlands. Additionally, through the Dutch at Dejima, Takashima managed to obtain cannons, field guns, and mortars, in doing so highlighting the importance of the modernization of the artillery forces of the bakufu army. In September 1840, Takashima Shūhan completed his memorandum, which was sent to the bakufu top administers. On 27 June 1841, Takashima was permitted to undertake the first modern Western military demonstration in Tokumarugahara (an area north of the capital city, Edo). He was heavily criticized by many, including bugyō Torii Tadateru, ${ }^{1}$ and was placed under investigation and house arrest on charges of subversion and conspiracy. Takashima's memorandum requires careful study in order to discover the reasons for the bakufu's response, which must also include a discussion of the Japanese financial situation at that time.
\end{abstract}

1 Torii Tadateru 鳥居忠耀 (1796-1873), metsuke 目付 (censor or inspector) and minami machi bugyō 南町奉行 (magistrate of the southern part of Edo) in the bakufu administration, was one of most active figures during the time of the Tenpo reforms, well known for his actions against people who had a strong interest in Western culture and military arts.

*Corresponding author: Sergey Tolstoguzov, Visiting Researcher, Osaka University of Economics and Law, Yao, Japan; Instructor, Department of Integrated Arts and Sciences, Hiroshima University, Higashihiroshima, Japan. E-mail: sergeytol@w6.dion.ne.jp 
Keywords: Takashima Shūhan, Tokugawa bakufu, Tokumarugahara, memorandum, artillery

\section{Introduction}

Despite appeals to the samurai spirit, the Meiji Restoration was accompanied by war that employed modern arms. Little evidence of the use of pikes and archery demonstrates that this war employed rifles and cannons, despite the fact that a samurai contingent fought on both sides. Swords were not as popular as rifles; additionally, mentions of arquebuses and other older firearms are as rare as those of pikes and archery. How did the Japanese manage to change weapons so radically and quickly? The impact of the Opium War was a significant factor and cannot be underestimated. The Japanese were fully aware of the overwhelming defeat of the Chinese at the hands of British troops. As such, some answers can be found by reviewing the Memorandum of Takashima Shūhan, ${ }^{2}$ which was linked to the Opium War.

The importance of this document is not limited to military matters. Takashima's Memorandum allows us to gain a deeper understanding of the nature of many of the principals of foreign relations that guided the leaders of the bakufu in its foreign policy. During the time of the Tokugawa bakufu, Japanese government officials closely monitored the situation outside their country, and received new information from both Chinese and Dutch sources.

For most of its existence, the Tokugawa bakufu maintained a foreign policy stance that was underscored by the term sakoku. ${ }^{3}$ This term, however, was borrowed from European studies of Japan, and may not fully reflect all the features of the existing principles of foreign policy conduct. As such, a more thorough investigation of Japanese foreign policy in the first half of the $19^{\text {th }}$

2 Takashima Shūhan 高島秋帆 (1798-1866), machi toshiyori 町年寄 (district head) of the Nagasaki Administration, hereditary samurai of Shogun and the third son of Takashima Shirōbei, in addition to being the master of the Takashima-ryū (the Takashima modern military school), who made a significant contribution to the spread of modern military knowledge and the production of modern arms (Jaundrill 2016). In 1840, he presented a memorandum and was permitted to conduct a demonstration in Tokumarugahara. In 1842, he was suddenly placed under arrest and lost his post in the Nagasaki Administration. In 1853, he was restored to his position and served as an adviser to the Nagasaki Administration and as a teacher in the military school created by the bakufu.

3 鎖国. 
century is required, which may provide a rich source of material from which to draw in order to better understand some of the basic principles of Japan's relations with the outside world.

The sakoku regime is widely discussed in the research literature because, as Marius Jansen ${ }^{4}$ states, "Japan itself was far from fully 'closed"”. Understanding sakoku only as 'isolation', however, does not represent the entire complexity of the situation. According to Ronald Toby, "continued intercourse with the West (...) would have meant that Japan maintained complete access to the most advanced scientific, industrial, and strategic developments in Europe, and [may] even have fostered an enduring Japanese scientific and industrial revolution". 5 The key element of Toby's approach is that "the bakufu, as a central authority, held firm control over foreign trade and diplomacy."6

The name 'Takashima Shūhan' is often-mentioned in Western research. Marius Jansen devotes roughly two pages to outlining Takashima's achievements and subsequent fate, concluding that "it was difficult for those who saw their whole identity threatened by the adoption of Western methods to reconcile themselves to such changes". ${ }^{7}$ Hence, Jansen focuses on political and ideological factors. This part of Jansen's book includes no references; however, we can assume that he primarily used the work of Arima Seiho, ${ }^{8}$ a well-known Japanese scholar, both in and outside of Japan, who published a short article in English in 1964 that can be used to represent his methods for evaluating Takashima Shūhan. ${ }^{9}$ The results of Seiho's studies are essential for an adequate understanding of Takashima's activities; admittedly, however, his research falls short of the required in-depth knowledge needed for the present study.

The Memorandum of Takashima Shūhan, which has never been translated into English, allows us to gain a deeper understanding of the nature of many of the principles of foreign relations that guided the leaders of the bakufu in establishing foreign policy. Furthermore, it also contributes information regarding the motives of the Order of 1842, which changed the priorities of the bakufu's foreign policy.

\footnotetext{
4 Jansen 2000: 92.

5 Toby 1984: xiv.

6 Hellyer 2009: 7.

7 Jansen 2000: 288.

8 Arima 1958, 1964.

9 Arima 1964.
} 


\section{Translation of the Memorandum of Takashima Shūhan (September 1840) ${ }^{10}$}

In the Year of the Mouse, ${ }^{11}$ a Dutch ship arriving at the port of Nagasaki brought a message that the British in Canton had caused a significant military disturbance. The same information was also relayed by Captain Xu Aytey, who heard about it prior to leaving China. For people of my low station ("dark and ignorant"), it is inexcusable to attract the attention of respected people without good reason. However, I cannot stop thinking about it. Even if what I believe does not meet with approval, it may be received positively by some. In the following, I present my humble thoughts.

Westerners and other barbarians use gunpowder weapons and warships as primary tools of warfare and employ gunnery as a primary means of defending their countries, having actively mastered the techniques of their use. In recent years, however, weapons have changed, and they have been tested in real combat conditions in a series of wars. Artillery technology, in particular, has changed dramatically. Compared to China, England is a much smaller territory; its military achievements may therefore, at times, appear difficult to understand, and the reasons for its victories not always immediately clear. In spite of this, China suffered significant defeats against England. I believe this to be the result of the weapons employed by British armies. China's defense strategies were well planned and certainly provided protection; however, the British fought without any difficulties, sometimes even playfully, using warships right from the start. Moreover, the Dutch openly state that the Chinese artillery led to children's taunts, which also occurred for the above reasons.

In the Imperial country, since ancient times, a divine martial art has been applied to fight various barbarians. During the Tenbun years, muskets began being used; following this, and up to the present, there has existed a need for gunpowder, the use of which I sincerely think is the right way. However, the shooting techniques in current artillery houses remains the same as those used in the West many centuries ago. Despite this, each house has its own school and carefully guards its techniques from others. In addition, many people only focus on external beauty and compete on this for fun. The government pays constant attention to the defense of the country, and deals with the artillery houses without recourse, regardless of the debate about benefits and drawbacks, and despite the fact that the public is still far from taking part in a discussion about

10 Translation based on Takashima 1974: 6-9.

111840. 
the development of artillery. If, on the contrary, this situation is known by the barbarians, the current state of defense may become inadequate. Various southern barbarians, including the soldiers of the defeated troops, will attack the vastness of the surrounding seas in war because they are more akin to thieves, who are not afraid of death and will do things that can cause resentment. In our land, it is possible that they can, through force, require supplies and water. It is not the case that we need to become dirty through revenge using our military art. In addition, artillery has not yet gained the necessary maturity, and therefore, in my opinion, this creates a situation where we have no choice.

In particular, it is of importance to Nagasaki, which is a place of commerce with foreign states; this being the case, we should fear to the maximum extent the possibility of emergencies, and we should be especially careful to prepare for them. My older colleagues and I were given orders about the study of artillery, and this is quite important in order to calm all men without rank who must give thanks a thousand times. In order to even slightly justify higher blessings and absolutely pure motives, I began to study artillery in the House of Ogino and others, but I could not find any satisfactory conditions there. To protect ourselves from barbarians, as I understand it, artillery is extremely important, and so I studied the various houses to cover this issue, especially the grounds and principles of gunnery, thinking about what would happen on the field in the case of real military action. I realized that the Dutch do indeed have grounds for laughing at the conditions of the artillery in our country. The techniques used by our houses and rounds of ammunition, including various secret methods, cannot even get close to the capabilities of bombs (explosive shells). I would kindly like to draw your attention to other spheres pertaining to the same situation. I am not going to say that the technique of houses is not polished, but their equipment is in the condition in which it came when it arrived from abroad many years ago, and unsuccessful shots and serious wounds are very possible, which is very dangerous. People of high rank do not want to practice shooting, and their arguments are easy to understand. Gunnery has become the activity of the poor samurai, but they cannot become the wings of the Imperial military system, something that I must admit with a heavy sigh.

Artillery is of paramount importance to the defense of the country. Let me say that the noble houses and all the other houses, up to the present time, have been engaged in the use of gunpowder, and we need to discard all arguments about advantages and disadvantages and radically turn the gunpowder case in our country under Heaven. If these houses turn to the real issues of defense, then the military power of our country will shine even more and, I think, the reign in our country will be long. I humbly ask you to consider accepting the mortars and other artillery techniques invented in recent times and consider the 
possibility of placing them on the external borders of Edo. In addition, there are general considerations regarding the equipping of the coast and the outer borders of Nagasaki presented by the Houses of Kuroda and Nabeshima. To provide comment from my modest thinking would be unforgivable audacity, thus I will refrain from commenting. I will humbly permit myself to say that, if my reasoning be accepted, it would result in great happiness for me.

In addition, in the case of an emergency, people from $5 \mathrm{kumi}^{12}$ would need to be in their places and be allocated only 3 to 4 men. This is very small. May I ask that this point is paid special attention to? Among the local officials are many who get considerable subsidiaries, and they can receive training on the normal days to engage in military affairs, so that, in case of emergency, they could help the bugyōsho. ${ }^{13}$ I humbly request that this proposal be considered.

I have humbly expressed many extraordinary thoughts above, perhaps for which it is difficult to avoid punishment for disrespect, but I humbly say that, throughout the year, I constantly think about what is happening in Canton, and even if I receive a reprimand, it will still be happiness for me.

\section{Nagasaki and sakoku}

In the Edo period, Nagasaki, Tsushima, and the Ryūkyū Islands were places of permanent contact with representatives of other states and nations. In his Memorandum, Takashima discusses, in particular, the importance of Nagasaki: "a place of commerce with foreign states; this being the case, we should fear to the maximum extent the possibility of emergencies, and we should be especially careful to prepare for them". ${ }^{14}$ The use of the verb 'to prepare' means, first of all, in a military direction.

Takashima Shūhan served as an official in Nagasaki and had a thorough knowledge of European weapons and tactics, but he was not the first person in the Takashima family who had an interest in foreign weapons and military training. At first, he learned from his father, Takashima Shirōbei, who also had an official post in the Nagasaki administration, and he also gained significant knowledge of European warfare during his stay in office because he supervised part of the coastal defense.

12 Koshō kumi, Shoinban kumi, Shinban kumi, Ōban kumi, and Kojūnin kumi.

13 奉行所, the office of the local administration at Nagasaki.

14 Takashima 1974: 6. 
Takashima had acquired, from 1823 to 1827, military information from the Chief of the Dutch factory, Jon Willem de Sturler, who was the Reserve Colonel of the Dutch army and had experience of the Napoleonic Wars, thus giving him extensive knowledge about armies, weapons, the military industry, and ballistic calculations. ${ }^{15}$ On the basis of Sturler's knowledge, Takashima was able to order not only simple books with sketches of European armies and maps, but also books that provided a more exhaustive description of artillery bombshells and grenades, army strategy and tactics, and the manufacturing of weapons.

Takashima's official post was based in Nagasaki, and this allowed him to obtain books and samples of weapons, that provided extensive opportunities to energetically study European weapons and tactics. He writes: "My older colleagues and I were given orders about the study of artillery, and (...) must give a thousand times thanks". ${ }^{16}$ Placing orders almost every year, he amassed a collection of manuscripts that contained more than one hundred volumes. In particular, he was interested in artillery, fortification, and coastal defense. This also led to a strong interest in European natural sciences. Furthermore, Takashima ordered several books about molding technology and the manufacturing of weapons and gunpowder from Holland.

Concerning the role of Nagasaki trade, it also seems important to draw attention to the fact that trade was based on transactions through orders and barter. Free trade was very difficult to control, and therefore, in Nagasaki, it was not possible to find a free market or a free flow of commodities, nor was it possible to get easy access to foreign merchants with a free circulation of foreign cash. Takashima bought items in Japan by order from the Dutch factories, and his orders brought him various items from Europe. Some items, including books and watches, were legally sold in Japan by Takashima, which could then pay for the Dutch orders. This was the usual way of conducting transactions, with foreigners and several officials from Nagasaki and Edo having access to this trade.

Takashima also placed orders for weapons on behalf of some other bakufu officials and various private lords from Kyushu and other regions. For instance, in 1836, Takashima placed an order for 80 rifles. According to the calculation of Arima Seiho, ${ }^{17}$ Takashima imported a total of 125 infantry rifles in the 1830 s. Several Nagasaki officials made orders for rifles and ammunition, including other machi toshiyori Hisamatsu Sekijiro ${ }^{18}$ and Fukuda Yasuemon. ${ }^{19}$

15 Arima 1964: 352-379.

16 Takashima 1974: 7.

17 Arima 1958.

18 The elder brother of Takashima Shūhan.

19 Ishida 2009: 303. 
In 1835, Takashima made orders for gewehrs (flintlock rifles) and two yager rifles, several pistols, 16-pound mortars, 16-pound howitzers, and two threepound field guns. In addition, he imported empty bombshells and grenades, ammunition belts, long glasses, more than a thousand flints, and many other items. Furthermore, in 1834 and 1835, he placed orders for casting molds for the production of grenades, as well as 16-pound howitzers, three-pound field guns, tartaric acid, and other items necessary for weapon production in Japan. ${ }^{20}$

His set of ideas regarding military training was called Takashima-ryū (the Takashima modern military school), and it substantially enlarged the number of people who understood the real gap between modern Western firearms and Japanese swords and arquebuses. Thus, the emergence of Takashima-ryū was a remarkable event for a country where contemporary military schools strongly stressed the use of old artillery.

\section{East Asia in the first half of the nineteenth century}

It is also essential that we keep in mind the worsening relations between Britain and China at this time. In 1839, Dutch merchants brought news of the exacerbation of the conflict between Britain and China over the opium trade and the appointment of Commissioner Lin Zexu. Later, other messages delivered by Chinese merchants brought information about an increase in tensions between the two countries and the beginning of armed conflict. Various people throughout Japan paid a great deal of attention to the situation in their neighboring country, as evidenced by the speculation that, as China was too big to attract the attention of England and Korea was too small, the next possible target of British policy could well be Japan.

Takashima wrote that, in 1840, a Dutch ship, which arrived at the port of Nagasaki, brought a message that the British in Canton had stirred up quite a disturbance. The same information was also relayed by Captain Xu Aytey, who had heard about it before leaving China. This report about British activities in Canton was actually the beginning of the Opium War. ${ }^{21}$

In May 1839, the Chinese Commissioner in Canton, Lin Zexu, demanded that the foreign traders turn over their opium. The following month, an enormous quantity of opium was destroyed, which took more than three weeks.

20 Arima 1958: 68-70.

21 Takashima 1974: 6. 
Growing tensions between China and Britain finally lead to the first Opium War (1840-1842).

In the tense atmosphere of 24 June 1839, the captain of an ordinary Dutch ship delivered the news about the conflict between Britain and China. These words were translated into Japanese, but in language which was very favorable to the Chinese and which included news about great trouble for the Europeans:

The illegal opium trade in Guangzhou was prohibited, and for that reason a high-ranking official from the capital was sent there. In addition, a strong order was issued not to hide stored opium, but to surrender it to Chinese authorities. This caused great trouble for the Europeans who had stored the opium. Furthermore, in the territory of China, if somebody heard about people who took opium, then he must punish that person regardless of his position. Furthermore, people who violate this order must be severely punished. ${ }^{22}$

Nevertheless, it was apparent that growing tensions could easily lead to open hostilities, and, in June 1840, news was delivered of the beginning of the first Opium War.

Ultimately, China's military losses in the war forced its rulers to sign treaties opening several new ports to foreign trade. The restrictions imposed under the Canton system were also abolished. Despite imperial prohibitions, the main reason for the war was the opium that had been traded, and a stunned Takashima wrote that the "British are fighting without any difficulty, and sometimes playfully", ${ }^{23}$ arguing that the British victory was being achieved by the use of modern weaponry and tactics.

Casualties for the Chinese army were more than one hundred times greater than those suffered by the British forces. According to a report submitted to the British government in 1847, total combat casualties in the first Opium War were sixty-nine killed and 451 wounded, while Chinese casualties were estimated at about 18,000 to $20,000 .^{24}$

All news about China came through Nagasaki, which was under full control of the bakufu officials. Takashima Shūhan, as one of the administrative officials, therefore had a great opportunity to deliver important information to the bakufu about modern achievements in the development of warfare and weaponry in Europe, and about the degree of backwardness of Japan, in order to increase the influence of modern weaponry and methods of warfare in Nagasaki.

England had become widely known in Japan since the "Phaeton incident" (Phaeton jiken), which related to the intrusion of the frigate Phaeton into the port

22 Mori 2001: 4.

23 Takashima 1974: 6

24 Purdue 2011. 
at Nagasaki in $1808 .^{25}$ Indeed, every educated man in the Edo bakufu, as well as in private domains, had firm knowledge about this foreign country and realized its important role in world politics.

England's victory over France in the Napoleonic Wars in 1815 had removed the last serious rival on the world stage. The British Empire began to expand exponentially after that, albeit in the form of territorial intrusion rather than in the traditional form of colonial political control. Britain took possession of Singapore, Malacca, and Burma. English activity created growing concern on the part of the bakufu 's officials when they received alarming information from a Dutch representative in Nagasaki. In 1823, Takahashi Kageyasu, ${ }^{26}$ one of the officials who collected information about the outside world for the leaders of the bakufu, made some notable remarks about the expansion of the British colonies and the strengthening of control over India. He noted that the British were dealing with this land (i.e. Calcutta) as their own country, sending a senior official, called a zeneraru (General, i.e. Governor-General), and keeping all the ships belonging to the country under control. ${ }^{27}$ Takahashi understood the importance of the growing British influence in India and the increasing political dependence of India on Britain.

The British maneuvers made not only bakufu officials anxious, but also many well-known intellectuals of the time. For example, Aizawa Seishisai ${ }^{28}$ wrote that England had annexed both ends of the African continent and was expanding its position in India. In addition, he wrote that the British vessels were using temporary stops in Far Eastern ports to draw maps, to measure the ocean's depth off Japan's coasts, and to probe defenses. ${ }^{29}$ According to Aizawa, Westerners had acquired many colonies located thousands of miles

25 In October 1808, an English frigate entered Nagasaki harbor to attack Dutch ships, capturing Dutch representatives. The captain of the British frigate also demanded water and food. The Nagasaki Magistrate immediately issued an order to Kyushu landlords to send additional military forces to support the Nagasaki garrison, and provided supplies to the English ship in order to gain more time. Meanwhile, the frigate left the harbor when the captain received information that the Dutch ships wouldn't visit Nagasaki that year. The Nagasaki Magistrate, Matsudaira Yasuhide, took responsibility by committing suicide by seppuku, and news of his death was widely circulated throughout the country.

26 Takahashi Kageyasu 高橋景保 (1785-1829), member of the Astronomy Bureau who became famous because of his connection to Siebold and ultimately died in prison. His office was in Edo, and this information circulated inside bakufu's officials.

27 Katō 1985: 249.

28 Aizawa Seishisai 会沢正志斎 (1782-1863), a Japanese thinker of the Mito school during the late Tokugawa period.

29 Wakabayashi 1986: 89. 
across the sea from their homelands, endeavoring to annex all nations in the world. $^{30}$

In 1825, the bakufu issued the Order to Repel Foreign Vessels, which demanded that all foreign vessels be driven away from Japanese waters, representing a clear expression of seclusionism. This order was mainly directed against small whaling ships but also against all coming "Southern Barbarians". 31

Aizawa Seishisai was not the only intellectual who was interested in information from abroad. Study of Western books and discussion of isolation policy were the goals of many groups organized in the 1830s. Members of a society called shoshikai, one of whom was Watanabe Kazan, started meeting in Edo in 1832, and the number of members rose steadily from four or five to twenty-six. They met occasionally and informally in order to exchange information about the West and discuss foreign books. ${ }^{32}$ Watanabe Kazan wrote that England had great resources and a naval power excelling that of other nations, and, for that reason, its foreign policy actions had to be kept continually in clear focus. ${ }^{33}$ Nevertheless, he was severely punished.

Takashima's Memorandum also demonstrates that the critics of the Order to Repel Foreign Vessels did not stop with the punishment of Watanabe Kazan:

\footnotetext{
Now, various southern barbarians, including the soldiers of the defeated troops, will attack the vastness of the surrounding seas in war because they are more akin to thieves, who are not afraid of death and will do things that can cause resentment. In our land, it is possible that they can, through force, require supplies and water. It is not the case where we need to become dirty through revenge using our military art. In addition, artillery has not yet gained the necessary maturity, and therefore, in my opinion, this creates a situation where we have no choice. ${ }^{34}$
}

\section{The demonstration of European firearms at Tokumarugahara}

Under the strong influence of British victories in China, in his Memorandum, Takashima Shūhan wrote:

30 Wakabayashi 1986: 90.

31 Wakabayashi 1986.

32 Abiko 1989: 200.

33 He was soon severely punished for having the courage to call for looking towards Britain without fear or favor.

34 Takashima 1974: 7. 
England, compared with China, has a much smaller territory, and its military achievements are not easily understood from the standpoint of ordinary common sense; the reasons for their victory are not immediately clear. In spite of this, they came, and China suffered huge defeats, while the British did not lose a single man. This is all, as I humbly think, thanks to the standard weapons and their use. ${ }^{35}$

Firearms and linear tactics were the key elements used by the British $a \mathrm{army}^{36}$ in this period. This fact was clear for Takashima, who stressed:

Westerners and other barbarians use gunpowder weapons and warships as the primary tools of warfare, employing gunnery as the foremost means of defending their country, and they have actively mastered the techniques of their use. In recent years, weapons have changed, and artillery technology has changed dramatically, having been tested in a series of wars in real combat conditions. ${ }^{37}$

In his Memorandum, Takashima wrote that artillery is of paramount importance for the defense of the country, and this statement can be seen as the core of his thinking. Takashima received Dutch infantry reglament and, in Nagasaki, organized the training of samurai in the linear tactics of the European armies, with the use of firearms and artillery. Various daimyō sent students to learn from Takashima. It was the beginning of the Takashima-ryū, or the branch of martial arts based on the study of Western military principles. Of course, it was not the same education as in European military schools for soldiers that emphasized line units' maneuvers. In detail, Takashima investigated the Dutch infantry reglament and, at Tokumarugahara, gave a demonstration not only of artillery but also the line infantry regiments or new army tactics, which had comprised the basis of European land armies from the middle of the 17th century to the middle of the nineteenth century. ${ }^{38}$

35 Takashima 1974: 6.

36 Linear tactics dominated from the middle of the seventeenth century in infantry units with an influx of hand guns. The Russian army also adopted linear tactics as part of their military strategy. The relatively short shooting range of rifles and slow reload (two to three rounds per minute) made massed formation firing essential for maximizing enemy casualties, so the infantry was aligned into long thin lines and fired volleys. The line was considered as the fundamental battle formation, as it allowed the largest deployment of firepower. A line consisted of two, three, or four ranks of soldiers in order to give them time to reload arms. Movement of the line was very slow, and if soldiers were not trained, breakdown of the formation was almost inevitable. Line tactics required a strict discipline and long training of simple movements.

37 Takashima 1974: 6.

38 The Russian army also adopted line infantry regiments as part of its military strategy from the time of Peter I. 
In his Memorandum, Takashima made some proposals, based on his knowledge of the European military, for the strengthening of the Japanese army. He believed that England achieved many benefits because of its progress in artillery and military tactics. Therefore, in his view, it was necessary to organize the study of European artillery and tactics. In addition, he proposed the adoption of mortars by the Japanese army so that they could be placed on the shore batteries in Nagasaki and Edo bay.

The Memorandum that Takashima sent to the capital was transmitted to another official, Torii Tadateru, who wrote a negative conclusion. The essence of his objections was in accord with the position of the main contemporary Japanese military schools that strongly stressed the core requirements of swordsmanship and personal courage. These sentiments were shared by many Japanese people, and the debate about which was more important, samurai courage or the quality of weaponry, continued until the Meiji Restoration. Despite the critical evaluation of the Torii Tadateru, Takashima Shūhan decided to move to Edo. In December 1840, he started his journey to the capital with a small group of samurai from Nagasaki training under him. In addition, he had several cannons and a number of rifles. Takashima arrived at the capital on February 7 of the following year and was immediately ready to begin demonstrations of advanced European military tactics and weapons; however, the leaders of the bakufu delayed the demonstration for a few months.

The use of the Dutch infantry reglament formation and European weapons was a very courageous step for the time, and many in the bakufu resisted the innovations based on European methods. Mizuno Tadakuni ${ }^{39}$ gave his consent only after a long period of consideration and waiting for the right opportunity. Demonstration of European military tactics was then synchronized with the Declaration of the Shogunal Will in May 1841. Although, in the words of the Shogun, there was no direct mention of military reform, the declaration of reform made by the Shogun had created a favorable environment for innovation, which, in the recent past, could have been considered a punishable offense. Only then was Takashima Shūhan permitted to demonstrate European tactics of firearm use in the town of Tokumarugahara near Edo.

According to pictures drawn, in 1841, about one hundred men were engaged at Tokumarugahara. Takashima had started selling weapons in Japan long before the Opium War, so he easily managed to increase his infantry contingent

39 Mizuno Tadakuni 水野忠邦 (1794-1851) was, as rōjū shuza 老中首座 (Head of the Shogun Council of Elders), a leading official in the bakufu in this period, also known for his Tenpo Reforms. 
to 99 men and to borrow not only European rifles but also a cannon for the demonstration.

The demonstration started with cannon shooting. A mortar and a howitzer demonstrated the firing range of the foreign weapons. Then, the infantry presented linear tactics and line maneuvers, such as shooting from lines and forming into a square. Under Takashima's command, ninety-nine men were equal to two platoons of a European army. So, Takashima, in a short time, managed to prepare not only artillery but also infantry units that would have been impossible without previous training. All of his soldiers were samurai from different parts of Japan, with the most numerous group coming from Mito and consisting of seven men.

In addition to line shooting, the Takashima unit also demonstrated a square formation, which was one of the main infantry formations used in the case of cavalry attacks. The square formation in Tokumarugahara had the form of a triangle with cannons in the corners (because he only had three field guns: a one, three, and four-pounder).

In armies of that time, the number of artillerists was fixed, even for the infantry support guns: four artillerists for all types of cannons. Also, the number of horses had to be fixed to two. The reports about Tokumarugahara did not mention horses, so cannons were moved by artillerists, with four additional men per cannon. Thus, we can conclude that the number of artillerists was 12 and another 12 men helped to move the cannons.

Takashima also displayed new uniforms worn by the military students. These articles of clothing did not resemble those in Europe, but they were also completely different from the traditional armor $\left(y o r o i^{40}\right.$ ) of the Japanese samurai. The most conspicuous part was a peaked hat worn instead a traditional helmet.

Despite the profound knowledge of the basic principles of line infantry regiment tactics that he demonstrated at Tokumarugahara, in his Memorandum, Takashima mainly stresses the merits of the artillery, which he possibly considered the most important aspect for the modernization of the Shogunal army. The merits of European artillery were clear from the experience of war in China. Nevertheless, Takashima did not propose comprehensive reform of the Shogunal army and made limited proposals, mainly concerning coastal defense.

For a short time, Takashima Shūhan enjoyed the patronage of the top leaders of the bakufu. He received gratitude from Mizuno Tadakuni and

40 鎧. 
consented to payments of $520 r y \bar{o}^{41}$ for his artillery, which he had brought with him. However, the bakufu was not ready to accept European weapons and European military tactics, the main reason being that the finances of the government were in extremely bad shape; once again, therefore, it was decided to shift the burden of cost to the daimyō and concentrate on the building of coastal batteries.

In July 1841, Egawa Hidetatsu ${ }^{42}$ was instructed to start construction in the place called Nirayama, casting rifles on the European model based on the technology proposed by Takashima. In September of the following year, the major daimyō were allowed to produce cannons. However, shortly after that, Takashima was placed under arrest.

From the time of the demonstration of European weapons at Tokumarugahara, part of the administrative staff of the bakufu, and some commanders of military units, expressed strong discontent and stood in opposition to Takashima's activities. They emphasized that the actual results of the use of European weapons were uncertain. Some of these critics had a rational base for argument, since the target for mortar was set at 800 meters. The first shooting range was about $300 \mathrm{~m}$, the second only at $100 \mathrm{~m}$, and the third between 400 and $600 \mathrm{~m} .{ }^{43}$ The result was that the shooting was not stable and the guns could not consistently hit their targets; they could only be used against targets like enemy castles and camps. Ultimately, bakufu top officials came to the conclusion that the radical innovations were undesirable. In his Memorandum, Takashima wrote: "Even if I receive a reprimand, it will still be happiness for me", ${ }^{44}$ but it is a historical irony that his punishment was to be much more severe than just a reprimand.

Takashima received a strong blow in the second half of 1842, when Torii Tadateru presented a report accusing Takashima of plotting a conspiracy. In October 1842, the authorities began to investigate these charges in connection with Takashima Shūhan. In the end, criminal charges were not pressed, but Takashima was accused of misappropriation of office funds in Nagasaki. All of his property was confiscated, and, at the end of 1842, he was put in prison, where he spent several years waiting for the end of the investigation. Later, he was transferred to house arrest, only to be finally released in 1853. Ultimately, he

41 Gold or silver coins.

42 Egawa Hidetatsu 江川英龍 (1801-1855), daikan of the bakufu, well known for his interest in Western knowledge.

43 Takashima 1974: 6.

44 Takashima 1974: 9. 
and his men from Nagasaki were replaced. They lost their positions, and control over foreign trade was returned to the hands of the bakufu.

\section{Problems of the bakufu}

In 1842-1843, the bakufu placed a new order for four cannons and several hundred rifles from a Dutch factory (more than was ordered while Takashima was still in office). Mizuno Tadakuni ordered 50 rifles. Other members of the Shogun Council of Elders, Hotta Masayoshi and Sanada Yukitsura, ordered 50 and 44 rifles, while the city administration of Nagasaki requested nearly one hundred. Also, the Japanese authorities sent an enquiry about the cost of building a steam ship with Dutch aid, or importing it from Holland. ${ }^{45}$ On account of the execution of this order, three cannons and 255 rifles were delivered the following year, and payment for this order, to the sum of 2265 ryō, was made in silver. ${ }^{46}$

In fact, the sum reminds us that the financial problems of the bakufu also had to be kept in mind in the case of the introduction of firearms. The weight of 2265 ryō in silver is more than $600 \mathrm{~kg}$ of chogin (or $72.48 \mathrm{~kg}$ of high quality silver, ${ }^{47}$ if we calculate one ryō equal to four silver ichibu). That is, payment was made based in silver, which could easily be used to increase the volume of trade, but it demanded huge amounts of precious metals that were being used to pay for the budget deficit.

At a time of increasing activity of the bakufu leaders, it was not accidental that, at the end of 1844, a letter was delivered from the King of the Netherlands, Willem II, who wrote that isolation of the country - avoiding contact with other powers - did not fit in with the new era, when the primary role would be played by steamers. Willem believed that the steps taken in the decree of 1842 were not sufficient and did not eliminate the risk of conflict with the great powers.

The tone of the Dutch King reveals that he understood that the recent steps to ease the strict rules of the expulsion of foreign vessels, and the desire of the bakufu to order items that represented the latest achievements in military and other equipment, highlighted a significant shift in the policies of the Japanese leaders. Nevertheless, the Japanese response was negative and did not raise the possibility of expecting any further changes. Mizuno Tadakuni's rival and

45 Satō 1980: 357.

46 Satō 1980: 357.

47 Author's calculation. 
successor as Head of the Shogun Council of Elders, Abe Masahiro, ${ }^{48}$ sent a negative response to a letter from the King of the Netherlands, making further expansion of trade relations impossible. Under these circumstances, the expectations of a breakthrough in foreign relations and the speedy modernization of the army were out of the question. The remaining weapons, with a long delay in delivery, came to Japan three years later in $1846 .{ }^{49}$ Despite the fact that Takashima was put under arrest, military modernization was not completely stopped nor prohibited. Rather, we should point out the slow speed of the modernization of the Tokugawa army.

Further, the compulsory re-equipment of the bakufu army with modern firearms required dozens of tons of silver, or many more resources than were available to the bakufu at that time. The country was still affected by the consequences of the Tenpo famine years (1833-1836), which greatly exacerbated the financial difficulties of the bakufu and strongly influenced the Shogun Council of Elders' decisions concerning the purchase of additional weapons.

The budget deficit was permanent and was only covered by re-coinage. In 1820-1835, coin minting increased the budget by an additional 200,000250,000 ryo $^{50}$ In 1838 and 1841, the amount of income from re-coinage amounted to more than a million $r y \bar{o}$, which was almost half of the budget revenues. In addition to the famine and various financial woes, there was also the cost of the restoration of the Western part of the Edo castle and officially sponsored events in connection with the transfer of the post of Shogun from Ienari to Ieyoshi. Thus, from a purely financial point of view, the idea of modernizing the military was out of the question. The bakufu had no money for large purchases of weapons abroad or for a large-scale construction program of coastal batteries. Thus, financial difficulties objectively prevented the rapid and radical strengthening of defensive capabilities.

In addition, Japan lacked the technical resources and expertise for the production of modern weapons. For some time, attempts to manufacture cannons inside the country had limited success due to technical problems in casting. The main problem was obtaining high enough temperatures during the smelting process. Without this, cannons were fragile, quickly breaking down and needing constant repair. For artillery production, books were ordered from Holland, but technological improvement was very slow. From 1843 to 1867, three hundred and forty-six Western-style cannons were made, of which only

48 Abe Masahiro 阿部正弘 (1819-1857).

49 Satō 1980: 357.

50 Kitajima 1966: 232. 
eighty were cast from iron, the rest of which were bronze. ${ }^{51}$ Most of these were not suitable for equipping coastal batteries because of their small caliber.

In 1842, the bakufu issued an order, which significantly changed the list of measures that the Japanese authorities could use in case of entry of foreign vessels in the country's ports. A decree of 1825, which prescribed no hesitation in repelling any foreign ship that appeared on the coast of Japan, was canceled. Instead, it was ordered that the reasons why the ship had come to the coast of Japan was to be heard. If it was due to compelling circumstances, then water, provisions, and other necessary materials were to be provided, and then the ship would be demanded to leave Japanese waters. In some ways, the Order of 1842 was a response to the current international situation.

In addition, we need to point to the connections between the ideas of Takashima and the Order of 1842. Takashima never actually mentioned the Order of 1825 as was one of the main tools of the sakoku regime, but rather stressed the challenges of the situation under it. In the Memorandum, Takashima does not propose radical changes of the existing policy, but mainly stresses the need to strengthen the defense of several places for contact with the foreign world, including Holland, China, and Korea. Even such modest proposals were met with a stern reaction.

The Order of 1842 was issued as a response to external pressures. The evidence strongly suggests that the response of the bakufu did not accurately match the seriousness of problems that were challenging Japan at that time. Clearly, it appears that the fear of losing the monopoly over foreign contacts was one of the reasons for the weak response.

\section{Conclusion}

Japan's ardent interest in European weapons had started long before the Opium War. The first sample of rifles and cannons arrived in Japan in the 1830s. This introduction to European military science consisted not only of a weapons cache but also schematic descriptions of rifles and cannons to make soldiers battle ready. In addition, Takashima Shūhan placed orders for books about European technology and natural science, which he thought would be useful for the reproduction of weapons in Japan, thus intending to overhaul the Japanese military by means of a European template. In this sense, his overall goal was to upgrade the production of weapons in Japan.

51 Yoshida 1985: 194. 
The reasons for Takashima's fate were not only the result of the Tokugawa period's cultural ideology, but the limits of Japan's technological infrastructure and financial stability were also important factors necessary for understanding why a comprehensive program of military modernization was rejected. For the Tokugawa bakufu, despite the obvious advantages of a modernized army, there were cultural, technical, and economic problems that essentially prevented such reform from happening. It is important to realize that, despite the fact that no real modernization of the military occurred until the Meiji Restoration, the Takashima-ryū did influence the military throughout the entire country. However, all of Takashima's efforts were ultimately narrowed down and channeled in the direction of teaching mere firing and shooting techniques. It was only once Japan finally entered into mainstream global modernization at the end of the Edo period that we see an acceptance of Western military models and weapons production. The efforts of Takashima Shūhan to increase Japan's military prowess during a time of British and European domination highlights the sharp contrast in political and cultural views that existed at the time in pre-modern Japan.

The Tokugawa bakufu was not completely closed to the outside world. The historical evidence indeed shows that it would be erroneous to think of Tokugawa Japan in terms of complete isolation; however, it does appear that the regime was highly authoritarian. In this context, we can better understand that the aim of such a policy was not complete isolation, but rather part of an attempt to monopolize and control contact with the outside world. Indeed, the theme of control runs through much of the history during this feudal period, suggesting a deep-rooted fear of exposing the daimyo and the daimyo system to influences that might constitute a threat to its hold on power.

\section{Bibliography}

Arima, Seiho 有馬成甫 (1958): Takashima Shūhan 高島秋帆. Tōkyō: Yoshikawa Kōbunkan.

Arima, Seiho (1964): “The Western Influence on Japanese Military Science, Shipbuilding, and Navigation”. Monumenta Nipponica 19.3/4: 118-145.

Abiko, Bonnie (1989): “Persecuted Patriot: Watanabe Kazan and Tokugawa Bakufu”. Monumenta Nipponica 44.2: 199-219.

Hellyer, Robert (2009): Defining Engagement: Japan and Global Contexts, 1640-1868. Cambridge: Harvard University Asia Center

Ishida, Chihiro 石田千尋 (2009): Nichiran Bōeki no Kōzō to Tenkai 日蘭貿易の構造と展開. Tōkyō: Yoshikawa Kobunkan.

Jansen, Marius (2000): Making of Modern Japan. Cambridge: Belknap Press of Harvard University Press. 
Jaundrill, D. Colin (2016): Samurai to Soldier: Remaking Military Service in Nineteenth-Century Japan. Ithaca: Cornell University Press.

Katō, Yūzō 加藤祐三 (1985): Kurobune zengo no Sekai 黒船前後の世界. Tōkyō: Chikuma Shobō. Kitajima, Masamoto 北島正元 (1966): Bakuhansei no Kumon 幕藩制の苦悶. Tōkyō: Chūō Kōronsha.

Mori, Mutsuhiko 森睦彦 (2001): “Ahen sensō tosite no kara fūsetsusho” 幕末の海外情報. In: Bakumatsu Ishin to Jōhō 幕末維新と情報. Edited by Tooru Hōya 徹保谷. Tōkyō: Yoshikawa Kōbunkan, 3-30.

Purdue, Peter C. (2011): The First Opium War: The Anglo-Chinese War of 1839-1842. Cambridge: Visualizing Cultures; Massachusetts Institute of Technology. https://ocw.mit.edu/ ans7870/21f/21f.027/opium_wars_01/index.html (22.10.2017).

Satō, Shōsuke 佐藤昌介 (1980): Yōgaku Kenkyū 洋学史の研究. Tōkyō: Chūō Kōronsha.

Takashima, Shūhan 高島秋帆 (1974 [1840]): Katsu Kaishū Zenshū 11: Rikugun Rekishi 1 勝海舟 全集 11: 陸軍歴史 1. Edited by Mitake Katsube 真長勝部, Sannosuke Matsumoto 三之介松 本 and Yūjirō Ōguchi 勇次郎大口. Tōkyō: Keisō Shobō, 6-9.

Toby, Ronald (1984): State and Diplomacy in Early Modern Japan: Asia in the Development of Tokugawa Bakufu. Princeton: Princeton University Press.

Tolstoguzov, Sergey (2017): “Rosia gun kara mita Takashima Shūhan no gunji kaikaku” ロシア 軍から見た高島秋帆の軍事改革. Higashi Ajia kenkyū 東アジア研究, N67, 65-72.

Wakabayashi, Bob Tadashi (1986): Anti-Foreignism and Western Learning in Early-Modern Japan: The New Theses of 1825. Cambridge: Council of East Asian Studies, Harvard University.

Yoshida, Mitsukuni (1985): “The Restoration and the History of Technology”. In: Meiji Ishin: Restoration and Revolution. Edited by Michio Nagai and Miguel Urritia. Tokyo: The United Nations University, 192-204. 